Vol. 1, Juli 2021

\title{
PENGARUH TOTAL ASSET TURNOVER DAN NET PROFIT MARGIN \\ TERHADAP PERTUMBUHAN LABA PADA PT. INDOFOOD SUKSES \\ MAKMUR, TbK TAHUN 2017-2019
}

\author{
Oleh \\ Firda Sulitsya Sudirman \\ Institut Bisnis Dan Keuangan Nitro Makassar \\ Email : firdasdrman@gmail.com
}

\begin{abstract}
Abstrak
Tujuan dari penelitian ini dimana untuk mengetahui apakah Total Asset Turnover dan Net Profit Margin berpengaruh terhadap pertumbuhan laba dari perusahaan PT Indofood Sukses Makmur Tbk. Variabel independen yang digunakan dalam penelitian ini terdiri dari Totoal Asset Turnover dan Net Profit Margin, sedangkan variabel dependennya yang digunakan yaitu pertumbuhan laba. Dimana pertumbuhan laba merupakan suatu indikasi bahwa terjadinya suatu perubahan kondisi ekonomi dalam suatu perusahaan, yaitu perubahan ke arah yang lebih baik apa bila perusahaan tersebut mendapatkan laba dan akan menjadi negatif apabila terjadi suatu perusahaan rugi, karena tujuan utama perusahaan adalah menghasilkan laba yang maksimal. Populasi dalam penelitian ini adalah laporan keuangan PT Indofood Sukses Makmur Tbk periode 2017-2019. Sampel yang digunakan dalam penelitian ini menggunakan teknik sampel jenuh. Sampel jenuh adalah teknik penentuan sampel bila semua anggota populasi digunakan sebagai sampel.
\end{abstract}

Kata Kunci : Total Asset Turnover, Net Profit Margin, Pertumbuhan laba 


\section{Jurnal Manajemen Keuangan}

Vol. 1, Juli 2021

\section{PENDAHULUAN}

Perkembangan dunia bisnis sekarang ini sangatlah pesat. Hal ini dapat dilihat dari semakin banyaknya perusahaan yang bersaing. Banyaknya perusahaan yang muncul mengakibatkan terjadinya dinamika bisnis yang berubah-ubah. Sehingga hal seperti ini dapat dilihat dari persaingan dalam dunia usaha yang semakin ketat, fenomena ini dapat dilihat pada perusahaan jasa, dagang dan manufaktur yang berada saat ini.

Aset merupakan bagian terpenting dari perusahaan yang harus dikelola dengan baik untuk mendapatkan manfaat bagi perusahaan, sekaligus mendorong tercapainya tujuan perusahaan. Aset adalah semua sumber ekonomi atau kekayaan yang dimiliki oleh suatu etnitas yang diharapkan dapat memberikan manfaat usaha dimasa depan. Aset merupakan harta atau kekayaan yang dimiliki oleh perusahaan, baik pada saat tertentu maupun periode tertentu (Kasmir 2017:39).

Tujuan utama dari suatu perusahaan adalah untuk menghasilkan laba. Laba (income disebut juga dengan earning atau profit) merupakan ringkasan hasil bersih aktivitas operasi usaha dalam periode tertentu yang dinyatakan dalam istilah keuangan. Perusahaan dapat mengalami kenaikan atau penurunan laba dari tahun sebelumnya ke tahun selanjutnya hal itu dinamakan perubahan laba. Penilaian terhadap kinerja keuangan perusahaan dapat dilakukan melalui analisa rasio keuangan.

Total asset turnover (Perputaran Aktiva) adalah rasio perputaran total aktiva yang menunjukkan perputaran total aktiva diukur dari volume penjualan, dengan kata lain kemampuan semua aktiva menciptakan penjualan (Hararap, 
Jurnal Manajemen Keuangan

Vol. 1, Juli 2021

2015:309). Rasio keuangan lain yang digunakan adalah profitabilitas. Rasio profitabilitas yang digunakan salah satunya adalah net profit margin. Net profit margin adalah rasio untuk menilai persentasi laba bersih yang didapat setelah dikurangi pajak terhadap pendapatan yang diperoleh dari penjualan.

Salah satu perusahaan yang memiliki aset terbesar adalah PT. Indofood Sukses Makmur, Tbk. Dimana perusahaan ini merupakan produsen berbagai jenis makanan dan minuman yang memiliki sebanyak 50 anak perusahaan. Menurut www.cnbcindonesia.com laba bersih PT. Indofood Sukses Makmur, Tbk tercatat 13,53\% secara tahunan menjadi Rp 1,35 triliun. Alhasil, margin bersih perusahaan tercatat naik dari $6,74 \%$ di kuartal I-2018 menjadi 7,04\% pada kuartal I-2019. Selain itu, dalam 3 bulan pertama tahun 2019, jumlah aset PT. Indofood Sukses Makmur, Tbk tumbuh tipis 1,6\% dibandingkan akhir tahun lalu. Pada kuartal I-2019 total aset perusahaan tercatat Rp 98,09 triliun dari akhir tahun lalu sebesar Rp 96,54 triliun. Sementara itu, total ekuitas hingga akhir Maret 2019 tercatat sebesar Rp 51,8 triliun.

Berdasarkan latar belakang yang telah diuraikan sebelumnya maka penulis tertarik untuk melakukan penelitian dengan judul: "Pengaruh Total Asset Turnover dan Net Profit Margin terhadap Pertumbuhan Laba pada PT. Indofood Sukses Makmur, Tbk". 
Jurnal Manajemen Keuangan

Vol. 1, Juli 2021

\section{TINJAUAN PUSTAKA}

\section{A. Landasan Teori}

\section{Pengertian Rasio Keuangan}

Pengertian rasio keuangan merupakan indeks yang menghubungkan dua angka akuntasi dan diperoleh dengan membagi satu angka dengan angka lainnya. Rasio keuangan digunakan untuk mengevaluasi kondisi keuangan dan kinerja perusahaan. Dari hasil rasio keuangan ini akan terlihat kondisi kesehatan perusahaan yang bersangkutan.

Rasio keuangan merupakan kegiatan membandingkan angkaangka yang ada dalam laporan keuangan dengan cara membagi satu angka dengan angka lainnya (Kasmir, 2017:104). Perbandingan dapat dilakukan antara satu komponen dengan komponen dalam satu laporan keuangan atau antar komponen yang ada di antara laporan keuangan. Kemudian angka yang di perbandingkan dapat berupa angka-angka dalam satu periode maupaun beberapa periode.

Hasil rasio keuangan ini digunakan untuk menilai kinerja manajemen dalam suatu periode apakah mencapai target seperti yang telah ditetapkan. Kemudian juga dapat dinilai kemampuan manajemen dalam memberdayakan sumber daya perusahaan secara efektif. Dari kinerja yang dihasilkan ini juga dapat dijadikan sebagai evaluasi hal-hal yang perlu dilakukan kedepan agar kinerja manajemen dapat ditingkatkan atau dipertahankan sesuai dengan target perusahaan, atau 
kebijakan yang harus diambil oleh pemilik perusahaan untuk melakukan perubahan terhadap orang-orang yang duduk dalam manajemen kedepannya.

Dalam praktiknya, analisis rasio keuangan suatu perusahaan dapat digolongkan menjadi sebagai berikut:

a. Rasio neraca, yaitu membandingkan angka-angka yang hanya bersumber dari neraca.

b. Rasio laporan laba rugi, yaitu membandingkan angka-angka yang hanya bersumber dari laporan laba rugi.

c. Rasio antarlaporan, yaitu membandingkan angka-angka dari sumber (data campuran), baik yang ada dineraca maupun di laporan laba rugi.

\section{Bentuk-bentuk Rasio Keuangan}

Untuk mengukur kinerja keuangan perusahaan dengan menggunakan rasio-rasio keuangan, dapat dilakukan dengan beberapa rasio keuangan. Setiap rasio keuangan memiliki tujuan, kegunaan dan arti tertentu. Kemudian setiap hasil dari rasio yang diukur diinterprestasikan sehingga menjadi berarti bagi pengambilan keputusan.

Menurut Kasmir (2017:106), bentuk-bentuk rasio keuangan adalah sebagai berikut :

a. Rasio Likuiditas (Liquiditiy Ratio), yaitu rasio yang menggambarkan kemampuan perusahaan dalam memenuhi kewajiban jangka pendek. 
1. Rasio Lancar (Current Ratio)

2. Rasio Sangat Lancar (Quick Ratio atau Acid Test Ratio)

b. Rasio Solvabilitas (Leverage Ratio), yaitu rasio yang digunakan untuk mengukur sejauh mana aktiva perusahaan dibiayai dengan utang.

1. Total utang dibandingkan dengan total aktiva atau rasio utang (Debt Ratio)

2. Jumlah kali perolehan bunga (Times Interest Earned)

3. Lingkup Biaya Tetap (Fixed Charge Coverage)

4. Lingkup Arus Kas (Cash Flow Coverage)

c. Rasio Aktivitas (Activity Ratio), yaitu rasio yang digunakan untuk mengukur tingkat efisiensi pemanfaatan sumber daya perusahaan (penjualan, sediaan, penagihan piutang dan lainnya) atau rasio untuk menilai kemampuan perusahaan dalam melaksanakan aktivitas sehari-hari.

1. Perputaran Sediaan (Inventory Turnover)

2. Rata-rata jangka waktu penagihan/perputaran piutang (Average Collection Period)

3. Perputaran aktiva tetap (Fixed Assets Turnover)

4. Perputaran total aktiva (Total Assets Turnover)

d. Rasio Profitabilitas (Profitability Ratio), yaitu rasio untuk menilai kemampuan perusahaan dalam mencari keuntungan atau laba dalam satu periode tertentu.

1. Margin laba penjualan (Profit Margin on Sales) 


\section{Jurnal Manajemen Keuangan}

Vol. 1, Juli 2021

2. Daya laba dasar (Basic Earning Power)

3. Hasil pengembalian total aktiva (Return on Total Assets)

4. Hasil pengembalian ekuitas (Return on Total Equity)

e. Rasio pertumbuhan (Growth Ratio), merupakan rasio yang menggambarkan kemampuan perusahaan mempertahankan posisi ekonominya ditengah pertumbuhan perekonomian dan sektor usahanya.

1. Pertumbuhan penjualan

2. Pertumbuhan laba bersih

3. Pertumbuhan pendapatan per saham

4. Pertumbuhan dividen per saham

f. Rasio penilaian (Valuation Ratio), yaitu rasio yang memberikan ukuran kemampuan manajemen dalam menciptakan nilai pasar usahanya di atas biaya investasi.

1. Rasio harga saham terhadap pendapatan

2. Rasio nilai pasar saham terhadap nilai buku.

\section{Total Asset Turnover}

a. Pengertian Total Asset Turnover

Perputaran total aset atau Total Asset Turnover merupakan bagian dari aktivitas. Rasio ini memperlihatkan seberapa efektif investasi yang dilakukan pada waktu pembuatan laporan keuangan, sehingga dapat diperkirakan apakah manajemen perusahaan mampu mengefektifkan modal yang ada sehingga nantinya dapat 
Vol. 1, Juli 2021

dibandingkan banyaknya penjualan yang terjadi tiap satuan asset yang dimiliki dengan menggunakan rasio ini.

Total Asset Turnover dapat digunakan untuk mengukur efisiensi penggunaan aktiva untuk menghasilkan penjualan. Total asset turnover merupakan rasio yang digunakan untuk mengukur perputaran semua aktiva yang dimiliki perusahaan dan mengukur berapa jumlah penjualan yang diperoleh dari tiap rupiah aktiva (Kasmir, 2017:185). Semakin besar total asset turnover maka semakin besar pula penjualan yang dapat dihasilkan dari suatu aktiva yang pada akhirnya memunculkan kas yang dapat diakui sebagai laba perusahaan. Perputaran total aset menunjukan bagaimana efektivitas perusahaan dalam menggunakan keseluruhan aset untuk menciptakan penjualan dan mendapatkan laba.

b. Faktor-Faktor yang mempengaruhi Total Aset Turnover

Total asset turnover digunakan untuk mengukur seberapa efektifnya pemanfaatan aktiva dalam menghasilkan penjualan jika perputaran aktiva perusahaan tinggi maka akan semakin efektif perusahaan dalam mengelola aktivanya. Beberapa faktor yang memengaruhi total asset turnover yaitu:

1) Penjualan

2) Total aktiva yang terdiri dari: 
Vol. 1, Juli 2021

a) Current Asset (Aktiva Lancar) yaitu, kas (cash), surat berharga (marketable securitas), piutang (account receivable), persediaan (inventories).

b) Fixed Aset (Aktiva Tetap) yaitu, tanah dan bangunan (land \& building) serta mesin (mecine).

Rasio total asset turnover ini melihat sejauh mana keseluruhan aset yang dimiliki oleh perusahaan terjadi perputaran secara efektif. Adapun rumus total asset turnover (Fahmi 2015:135) adalah :

$$
\text { Total Aset turnover }=\frac{\text { Penjualan Bersih }}{\text { Total Aktiva }}
$$

\section{Net Profit Margin}

Net profit margin adalah rasio profitabilitas untuk menilai persentase laba bersih yang didapat setelah dikurangi pajak terhadap pendapatan yang diperoleh dari penjualan. Rasio ini mengukur laba bersih setelah pajak terhadap penjualan. Hubungan laba bersih dengan penjualan kerap kali dipakai untuk mengevaluasi efisiensi perusahaan dalam mengendalikan biaya dan beban yang berkaitan dengan penjualan, yaitu apabila perusahaan menurunkan beban realitanya terhadap penjualan, maka perusahaan akan memiliki lebih banyak dana untuk kegiatan-kegiatan usaha lainnya.

Menurut Kasmir (2012:197) mengemukakan bahwa, Net Profit Margin (NPM) merupakan hubungan antara laba bersih setelah pajak dengan penjualan menunjukkan kemampuan manajemen dalam menjalankan perusahaan sampai cukup berhasil dalam memulihkan 


\section{Jurnal Manajemen Keuangan}

Vol. 1, Juli 2021

atau mengendalikan harga pokok barang dagangan/jasa, beban operasi, penyusutan, bunga pinjaman dan pajak.

Berdasarkan definisi diatas dapat disimpulkan bahwa net profit margin adalah salah satu rasio keuangan yang digunakan untuk mengukur laba bersih perusahaan dari hasil aktivitas penjualan yang dihasilkan setiap bulannya atau setiap tahunnya. Net profit margin berfungsi untuk mengetahui laba perusahaan dari setiap penjualan atau pendapatan perusahaan. Menurut Kadir dan Phang (2012) bahwa faktor-faktor yang mempengaruhi net profit margin adalah sebagai berikut :

a. Current Ratio (Rasi Lancar)

b. Debt Ratio (Rasio Utang)

c. Sales Growth (Pertumbuhan Penjualan)

d. Inventory Turnover Ratio (Perputaran Persediaan)

e. Receible Turnover Ratio (Rasio Perputaran Piutang)

f. Working Capital Turnover (Rasio Perputaran Modal Kerja).

Dengan demikian net profit margin merupakan harapan untuk mendapatkan laba perusahaan secara berkelanjutan, bukanlah suatu pekerjaan yang gampang tetapi memerlukan perhitungan yang cermat dan teliti dengan memperhatikan faktor-faktor yang berpengaruh terhadap net profit margin karena rasio ini menunjukkan berapa besar persentase laba bersih yang diperoleh dari setiap penjualan. Semakin besar rasio ini, maka dianggap semakin baik kemampuan perusahaan untuk mendapatkan laba yang tinggi. 
Vol. 1, Juli 2021

Adapun rumus rasio net profit margin (Fahmi 2015:136) adalah sebagai berikut :

$$
\text { Net Profit Margin }=\frac{\text { Laba Bersih Setelah Pajak }}{\text { Penjualan }}
$$

\section{Pertumbuhan Laba}

Pada umumnya ukuran yang sering kali digunakan untuk menilai keberhasilan manajemen suatu perusahaan adalah melihat laba yang diperoleh perushaan. Menurut Subramanyam dan Wild (2014:25), laba (earnings) atau laba bersih (net icome) mengindikasikan profitabilitas perusahaan. Laba mencerminkan pengembalian kepada pemegang ekuitas untuk periode bersangkutan, sementara pos-pos dalam laporan merinci bagaimana laba didapat.

Laba sebagai suatu alat prediktif yang membantu dalam peramalan laba mendatang. Nilai laba dimasa lalu, yang didasarkan pada biaya historis dan nilai berjalan, terbukti berguna dalam meramalkan nilai mendatang, dengan demikian suatu perusahaan dapat mengetahui perubahan laba tiap tahun.

Perbandingan yang tepat atas pendapatan dan biaya tergambar dalam laporan laba rugi. Penyajian laba melalui laporan tersebut merupakan fokus kinerja perusahaan yang penting. Kinerja perusahaan merupakan hasil dari serangkaian proses dengan mengorbankan berbagai sumber daya. Adapun salah satu parameter penilaian kinerja perusahaan tersebut adalah pertumbuhan laba.

Pertumbuhan laba merupakan parameter untuk menilai suatu kinerja perusahaan. Pertumbuhan laba adalah kenaikan maupun 
Vol. 1, Juli 2021

penurunan laba yang terjadi tiap tahun. Hasilnya dapat dibandingkan dengan laba sebelumnya, sehingga diketahui angka pertumbuhannya (Andriyani, 2015:346). Menurut Hararap (2015:310) pertumbuhan laba adalah rasio yang menunjukkan kemampuan perusahaan meningkatkan laba bersih dibanding tahun sebelumnya. Cara pengukuran pertumbuhan laba yaitu, laba saat ini dikurangkan dengan laba sebelumya.

Menurut Angkoso (2006) pertumbuhan laba dipengaruhi oleh beberapa faktor antara lain sebagai berikut :

a. Besarnya perusahaan

Semakin besar suatu perusahaan, maka ketepatan pertumbuhan laba yang diharapkan semakin tinggi.

b. Umur perusahaan

Perusahaan yang baru berdiri kurang memiliki pengalaman dalam meningkatkan laba, sehingga ketepatannya masih rendah.

c. Tingkat leverage

Bila perusahaan memiliki tingkat utang yang tinggi, maka manajer cenderung memanipulasi laba sehingga dapat mengurangi ketepatan pertumbuhan laba.

d. Tingkat penjualan

Tingkat penjualan dimasa lalu yang tinggi, semakin tinggi tingkat penjualan dimasa yang akan datang sehingga pertumbuhan laba semakin tinggi.

e. Perubahan laba masa lalu 


\section{Jurnal Manajemen Keuangan}

Vol. 1, Juli 2021

Semakin besar perubahan laba masa lalu, semakin tidak pasti laba yang diperoleh di masa mendatang.

Pertumbuhan laba merupakan selisih laba bersih tahun tertentu dengan laba bersih tahun sebelumnya dibagi dengan laba bersih tahun sebelumnya. Menurut Hararap (2015:310) pertumbuhan laba dapat dirumuskan sebagai berikut :

$$
\mathbf{Y}=\frac{Y(t)-Y(t-1)}{Y(t-1)}
$$

Keterangan :

$$
\begin{array}{ll}
\mathrm{Y} & : \text { Pertumbuhan laba } \\
\mathrm{Y}(\mathrm{t}) & : \text { Laba tahun tertentu } \\
\mathrm{Y}(\mathrm{t}-1) & : \text { Laba tahun sebelumnya }
\end{array}
$$

\section{B. Penelitian Terdahulu}

a) Sholiha (2014)

Penelitian ini berjudul "Analisis pengaruh Current Ratio (CR), Debt To Equity Ratio (DER), Total Asset Turnover (TAT) dan Net Profit Margin (NPM) perubahan laba pada perusahaan manufaktur yang terdaftar di BEI periode 2010-2012". Data diperoleh dengan metode purposive sampling. Maka diperoleh sampel sebanyak 88 perusahaan.

Hasil dari penelitian ini menunjukkan bahwa secara parsial Debt To Equity Ratio dan Total Asset Turnover yang berpengaruh signifikan terhadap perubahan laba, sedangkan Current Ratio dan Net Profit Margin tidak berpengaruh signifikan terhadap perubahan.

b) Andrian (2016) 
Vol. 1, Juli 2021

Penelitian ini berjudul "Analisis Pengaruh Rasio Keuangan Terhadap Pertumbuhan Laba pada Perusahaan Food and Baverages yang Terdaftar diBursa Efek Indonesia (BEI) periode 2009-2013". Sampel dalam penelitian ini dilakukan secara purposive sampling. Berdasarkan kriteria pengambilan sampel, maka diperoleh 15 Perusahaan Food and Baverages yang terdaftar di Bursa Efek Indonesia.

Hasil dari penelitian ini yaitu bahwa secara parsial Current Ratio tidak berpengaruh signifikan terhadap pertumbuhan laba, Debt To Asset Ratio berpengaruh signifikan positif terhadap pertumbuhan laba, Total Asset Turnover berpengaruh positif signifikan terhadap pertumbuhan laba, Net Profit Margin berpengaruh positif signifikan terhadap pertumbuhan laba.

c) Daga, R (2021)

Penelitian ini berjudul "Pengaruh Program Corporate Social Responsibility Terhadap Pendapatan Usaha Kecil Menengah Pada PT. Angkasa Pura I (Persero) Cabang Makassar" yang mengambil data hasil monitoring unit PKBL pada tahun 2013. Berdasarkan hasil analisis regresi sederhana dapat disimpulkan bahwa program corporate social responsibility berpengaruh positif dan signifikan terhadap pendapatan usaha kecil menengah. 
Jurnal Manajemen Keuangan

Vol. 1, Juli 2021

C. Kerangka Pikir

Gambar 2.1

Kerangka Pikir

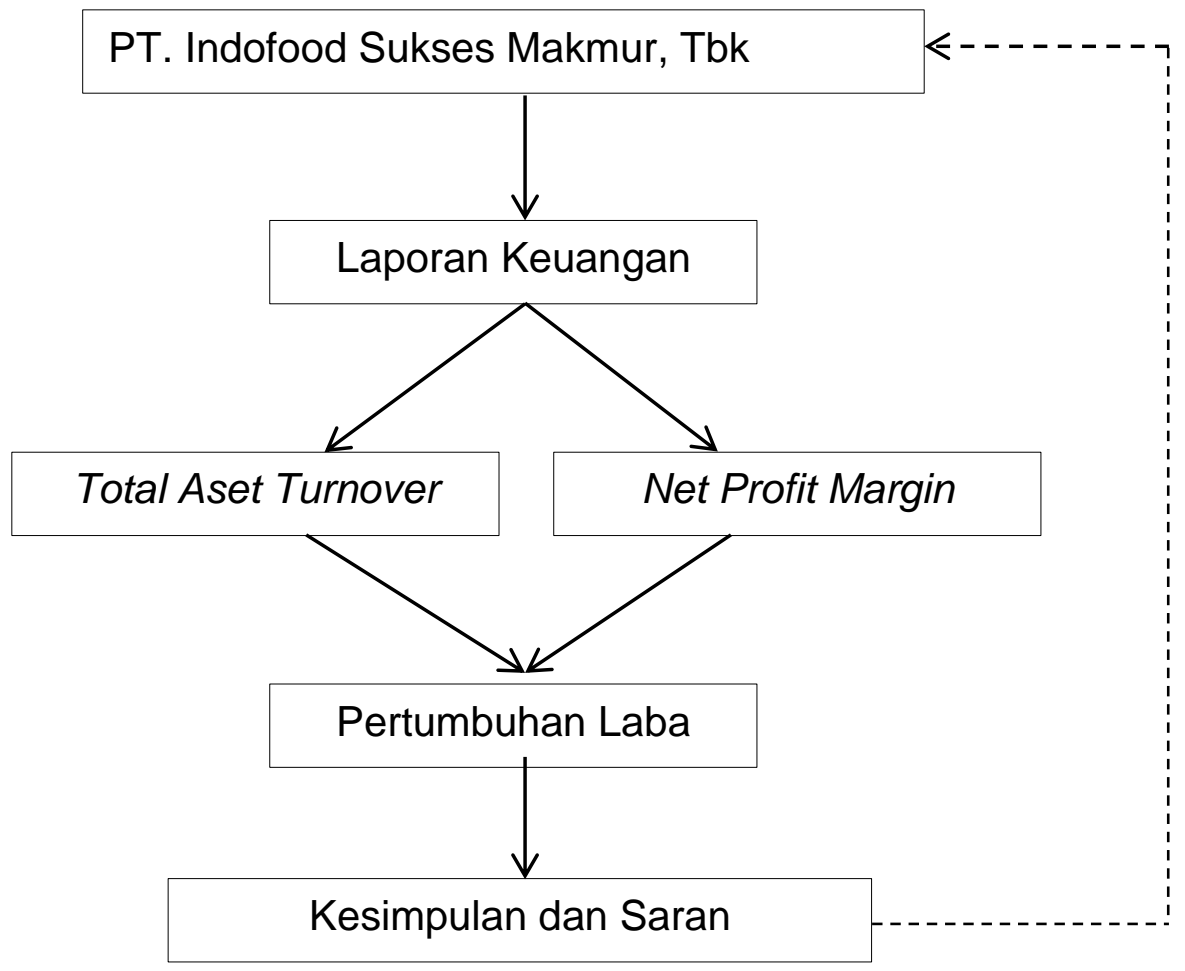

Keterangan :

Berdasarkan gambar 2.1 yang telah digambarkan sebelumnya, dimana penelitian ini dilakukan di Bursa Efek Indonesia pada PT. Indofood Sukses Makmur, Tbk. Dengan melihat laporan keuangan yang akan berfokus untuk menganalisis seberapa besar pengaruh Total Asset Turnover dan Net Profit Margin terhadap pertumbuhan laba, sehingga dapat dihasilakan kesimpulan dan saran untuk dijadikan bahan pertimbangan bagi investor yang ingin membeli atau menjual saham. 
Jurnal Manajemen Keuangan

Vol. 1, Juli 2021

\section{METODE PENELITIAN}

\section{A. Lokasi Dan Waktu Penelitian}

Untuk memperoleh data yang dibutuhkan dalam penelitian ini penulis melakukan pengambilan data pada situs resmi PT. Bursa Efek Indonesia yaitu www.idx.co.id dan website PT. Indofood Sukses Makmur, Tbk. Waktu penelitian ini dilakukan kurang lebih selama 1 (satu) bulan.

B. Jenis Dan Sumber Data

\section{Jenis Data}

Jenis data yang digunakan adalah data kuantitatif, yaitu data yang berupa laporan keuangan perusahaan PT. Indofood Sukses Makmur Tbk di Bursa Efek Indonesia.

\section{Sumber Data}

Sumber data yang digunakan dalam penelitian ini adalah data sekunder yaitu data yang tidak langsung didapatkan dari objek penelitian tapi diperoleh dalam bentuk data yang telah dikumpulkan, diolah dan dipublikasikan oleh pihak lain yaitu Bursa Efek Indonesia melalui Galeri Investasi Institut Bisnis dan Keuangan Nitro.

\section{Teknik Pengumpulan Data}

Teknik pengumpulan data yang digunakan dalam penelitian ini meliputi :

1. Penelitian Kepustakaan (Library Research), yaitu penelitian yang dilakukan dengan menggunakan beberapa teori dari literatur-literatur dan jurnal serta situs-situs internet yang berhubungan dengan masalah yang dibahas dalam penelitian ini. 
Vol. 1, Juli 2021

2. Penelitian Dokumentasi (Documentation Research), yaitu penelitian yang dilakukan dengan menggunakan dokumen-dokumen lain yang berkaitan dengan penelitian ini.

E. Populasi Dan Sampel

\section{Populasi}

Populasi yang digunakan dalam penelitian ini adalah laporan keuangan PT. Indofood Sukses Makmur, Tbk periode 2017-2019.

\section{Sampel}

Sampel yang digunakan dalam penelitian ini menggunakan teknik sampel jenuh. Sampel jenuh adalah teknik penentuan sampel bila semua anggota populasi digunakan sebagai sampel.

\section{F. Definisi Operasional Penelitian}

1. Total Asset Turnover adalah rasio yang memperlihatkan adanya efektivitas perusahaan dalam menggunakan keseluruhan aset untuk menciptakan penjualan dan mendapatkan laba. Rumus yang digunakan adalah sebagai berikut :

$$
\text { Total Asset Turnover }=\frac{\text { Penjualan Bersih }}{\text { Total Aktiva }}
$$

2. Net Profit Margin adalah rasio yang berfungsi untuk mengetahui laba perusahaan dari setiap penjualan atau pendapatan perusahaan. Adapun rumus yang digunakan adalah sebagai berikut :

$$
\text { Net Profit Margin }=\frac{\text { Laba Bersih Setelah Pajak }}{\text { Penjualan }}
$$


3. Pertumbuhan Laba adalah selisih laba bersih tahun tertentu dengan laba bersih tahun sebelumnya dibagi dengan laba bersih tahun sebelumnya. Adapun rumus yang digunakan adalah sebagai berikut :

$$
Y=\frac{Y(t)-Y(t-1)}{Y(t-1)}
$$

\section{G. Analisis Data}

Analisis data yang digunakan dalam penelitian ini adalah deskriptif kuantitatif, yaitu:

\section{Uji Normalitas}

Pengujian normalitas data penelitian adalah menguji apakah dalam model statistik variabel-variabel penelitian terdistribusi normal atau tidak. Model regresi yang baik adalah memiliki distribusi normal atau mendekati normal atau tidak, maka dapat dilakukan dengan cara normal P-Plot. Adapun dasar pengambilan keputusan:

1) Jika data menyebar di sekitar garis diagonal dan mengikuti arah diagonal atau grafik histogramnya menunjukan pola distribusi normal, maka model regresi memenuhi asumsi normalitas.

2) Jika data menyebar jauh dari garis diagonal dan/atau tidak menunjukan pola distribusi normal maka model regresi tidak memenuhi asumsi normalitas.

\section{Analisis Regresi Linear Berganda}

Analisis regresi linear berganda adalah hubungan secara linear antara dua atau lebih variabel independen (X1, X2,X3....Xn) dengan variabel dependen $(\mathrm{Y})$. Analisis ini untuk mengetahui arah hubungan 
antara variabel independen dengan variabel dependen apakah masingmasing variabel independen berhubungan positif atau negatif dan untuk memprediksi nilai dari variabel dependen apabila nilai variabel independen mengalami kenaikan atau penurunan. Persamaan regresi linear berganda sebagai berikut:

$$
Y=a+b 1 X 1+b 2 X 2+e
$$

\section{Keterangan:}

$$
\begin{array}{ll}
\mathrm{Y} & =\text { Pertumbuhan Laba } \\
\mathrm{X} 1 & =\text { Total Aset Turnover } \\
\mathrm{X} 2 & =\text { Net Profit Margin } \\
\mathrm{a} & =\text { Konstanta } \\
\mathrm{b} 1, \mathrm{~b} 2, & =\text { Koefisien Regresi } \\
\mathrm{e} & =\text { Standar Error }
\end{array}
$$

\section{a. Uji Hipotesis (Uji t Parsial)}

Untuk menguji hipotesis tentang kekuatan variabel independen terhadap variabel dependen, maka pada penelitian ini menggunakan Uji statistic $t$ (parsial) yang menunjukan seberapa jauh Uji-t digunakan untuk melihat pengaruh variabel independen. Uji $\mathrm{t}$ digunakan untuk menguji signifikan pengaruh variabel independen secara parsial terhadap variabel dependen. Uji ini dilakukan dengan menggunakan SPSS statistics 21.

Signifikan atau tidaknya pengaruh variabel dependen dilihat dari nilai profitabilitas (nilai sig). dari t rasio masing-masing variabel independen pada taraf uji $\mathrm{a}=5 \%(0,05)$. 


\section{b. Koefisien determinasi}

Koefisien determinasi ( $R$ square) menunjukan seberapa besar variabel independen menjelaskan variabel dependennya. Apabila nilai $\mathrm{R}$ square makin mendekati satu, maka variable-variabel independennya telah memberikan variasi variabel dependen.

\section{Uji Asumsi Klasik}

Pengujian asumsi klasik ini menggunakan :

\section{a. Uji Multikolinearitas}

Uji Multikolinearitas bertujuan untuk menguji apakah dalam persamaan regresi ditemukan adanya korelasi antar variabel bebas. Dalam model regresi yang baik seharusnya tidak terjadi korelasi diantara variabel bebas. Multikolinearitas akan menyebabkan koefisien regresi bernilai kecil dan standar error bernilai besar sehingga pengujian variabel bebas secara individu akan menjadi tidak signifikan. Untuk menguji ada tidaknya gejala multikolinearitas antara variabel independen digunakan Varience Inflation Factor (VIF). Apabila VIF > 10, terjadi multikolinearitas. Sebaliknya jika VIF < 10, tidak terjadi multikolinearitas.

\section{b. Uji Heteroskedastistas}

Uji Heteroskedastistas bertujuan untuk menguji apakah dalam model regresi terjadi ketidaksamaan varian dari residual atau pengamatan ke pengamatan lain. Salah satu cara untuk mendeteksi ada atau tidaknya heteroskedastistas adalah melihat grafik plot antara nilai prediksi variabel tidak bebas (ZPRED) 
Vol. 1, Juli 2021

dengan residualnya (SRESID). Deteksi ada atau tidaknya pola tertentu pada grafik Scatterplot. dengan dasar analisisnya sebagai berikut:

1) Jika ada pola tertentu, seperti titik-titik yang ada membentuk pola tertentu yang teratr (bergelombang. melebar kemudian menyempit) maka mengidikasikan telah terjadi heteroskedastisitas.

2) Jika tidak ada pola yang jelas, serta titik-titik menyebar diatas dan dibawah angka 0 pada sumbu $\mathrm{Y}$, maka tidak terjadi heteroskedastisitas.

\section{c. Uji Autokorelasi}

Uji Autokorelasi adalah untuk menguji apakah dalam suatu model regresi linear ada korelasi antara penganggu periode $t$ dengan kesalahan pada periode t-1 (sebelumnya). Jika terdapat korelasi, maka dinamakan ada problem autokorelasi. Model regresi yang baik adalah regresi yang bebas dari autokorelasi salah satu cara yang dapat digunakan untuk mendeteksi ada tidaknya autokorelasi adalah uji Durbin-Watson (D-W test).

Cara pengujiannya dengan membandingkan nilai DurbinWatson (d) dengan dl atau du tertentu atau dengan melihat table Durbin Watson yang telah ada klasifikasinya untuk menilai perhitungan (d) yang diperoleh akibat dari adanya autokorelasi dalam regresi, koefisien regresi diperoleh menjadi tidak efisien, artinya tingkat kesalahannya menjadi sangat besar dan koefisien 


\section{Jurnal Manajemen Keuangan}

Vol. 1, Juli 2021

regresi menjadi tidak stabil. Untuk menguji ada tidaknya autokorelasi dari data residual terlebih dahulu dihitung nilai satitistik Durbin-Watson (D-W test) sebagai berikut:

1) Jika $d-w<d l$, berarti terdapat autokorelasi positif.

2) Jika $d-w>(2-d l)$, berartit terdapat autokorelasi negatif.

3) Jika du < d-w (2-dl), berarti tidak terdapat autokorelasi.

4) Jika dl $<\mathrm{d}-\mathrm{w}<\mathrm{du}$ atau (2-du), berarti tidak dapat disimpulkan.

\section{KESIMPULAN}

Dari hasil penelitian ini menggunakan dua metode dalam mengumpulkan data yaitu dengan metode penelitian kepustakaan dan penelitian dokumentasi. Adapun sumber data yang digunakan dalam penelitian ini adalah data sekunder yang didapatkan dan terbitkan dari Bursa Efek Indonesia dan website PT. Indofood Sukses Makmur, Tbk tahun 2017-2019. Variabel independen yang digunakan dalam penelitian ini terdiri dari Totoal Asset Turnover dan Net Profit Margin, sedangkan variabel dependennya yang digunakan yaitu pertumbuhan laba. Sehingga kita nantinya kita dapat mengetahui apakah Total Asset Turnover dan Net Profit Margin berpengaruh terhadap pertumbuhan laba pada PT. Indofood Sukses Makmur, Tbk atau tidak. 
Vol. 1, Juli 2021

\section{DAFTAR PUSTAKA}

Daga, R. (2021). PENGARUH PROGRAM CORPORATE SOCIAL RESPONSIBILITY TERHADAP PENDAPATAN USAHA KECIL MENENGAH PADA PT. ANGKASA PURA I (Persero) CABANG MAKASSAR.

Andrian, Fitriano. 2016. Analisis Pengaruh Rasio Keuangan Terhadap Pertumbuhan Laba pada Perusahaan Food and Baverages yang terdaftar di Bursa Efek Indonesia periode 2009-2013. Jurnal Riset Akuntasi. Vol.13 No.1.2016.

Fahmi, Irham. 2015. Analisis Laporan Keuangan. Alfabeta:Bandung

Hararap. 2015. Analisis Laporan Keuangan. Jakarta:Rajawali.

Kadir, Abdul, Sthefanie Barceleona Phang. 2012. Analisis Faktor-faktor yang Mempengaruhi Net Profit Margin Perusahaan Manufaktur yang Terdaftar Pada Bursa Efek Indonesia. Jurnal Manajemen dan Akuntansi Vol. 13 No.1.1.April 2012.

Kasmir. 2012. Analisis Laporan Keuangan. Jakarta:PT. Rajagrafindo Persada

---------, 2015. Analisis Laporan Keuangan. Jakarta:PT.Rajagrafindo Persada.

2017. Analisis Laporan Keuangan. Jakarta:Rajawali

Puspita, Intan. 2019 Pengaruh Total Asset Turnover dan Return On Asset Terhadap Pertumbuhan Laba (Survei pada perusahaan sub sektor makanan dan minuman yang terdaftar di BEI periode 2011-2015). Jurnal Riset Akuntansi-Volume XI/No.1/April 2019.

Sholiha,Farihatus. 2014. Analisis Pengaruh Current Ratio (CR), Debt To Equity Ratio (DER), Total Assets Turnover (TAT) dan Net Profit Margin (NPM) Perubahan Laba pada Perusahaan Manufaktur yang Terdaftar di BEI periode 2010-2012. Jurnal Riset Akuntansi.Vol.11 No.1.1.April 2014. 